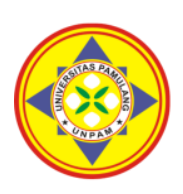

\title{
PENGARUH KOMPENSASI DAN LINGKUNGAN KERJA TERHADAP KINERJA KARYAWAN PADA PT. INDRIYA LIFEART DEVELOPMENT DI JAKARTA
}

\author{
${ }^{1 *}$ Yan Kristian Halomoan, ${ }^{2}$ Abdullah, ${ }^{3}$ Laila Listiani Putri \\ Universitas Pamulang, Tangerang Selatan, Banten, Indonesia \\ *dosen02487@unpam.ac.id
}

\begin{abstract}
Abstrak
Penelitian ini bertujuan untuk mengetahui pengaruh kompensasi dan lingkungan kerja terhadap kinerja karyawan pada PT. Indriya Lifeart Development di Jakarta. Metode yang digunakan adalah explanatory research dengan teknik analisis menggunakan analisis statistik dengan pengujian regresi, korelasi, determinasi dan uji hipotesis. Hasil penelitian ini kompensasi berpengaruh signifikan terhadap kinerja karyawan sebesar 48,2\%, uji hipotesis diperoleh $\mathrm{t}$ hitung $>\mathrm{t}$ tabel atau $(7,960>1,995)$. Lingkungan kerja berpengaruh signifikan terhadap kinerja karyawan sebesar 34,6\%, uji hipotesis diperoleh $\mathrm{t}$ hitung $>\mathrm{t}$ tabel atau $(5,995>1,995)$. Kompensasi dan lingkungan kerja secara simultan berpengaruh signifikan terhadap kinerja karyawan dengan persamaan regresi $Y=10,510+0,452 X 1+$ $0,302 X 2$ dan kontribusi pengaruh sebesar $55,7 \%$, uji hipotesis diperoleh $\mathrm{F}$ hitung $>\mathrm{F}$ tabel atau $(42,054$ $>2,740$ ).
\end{abstract}

Kata Kunci: Kompensasi, Lingkungan Kerja, Kinerja Karyawan

\section{Abstract}

This study aims to determine the effect of compensation and work environment on employee performance at PT. Indriya Lifeart Development in Jakarta. The method used is explanatory research with analytical techniques using statistical analysis with regression, correlation, determination and hypothesis testing. The results of this study that compensation has a significant effect on employee performance by $48.2 \%$, hypothesis testing is obtained $t$ count $>t$ table or $(7,960>1,995)$. The work environment has a significant effect on employee performance by $34.6 \%$, hypothesis testing is obtained $t$ count $>t$ table or $(5,995>1,995)$. Compensation and work environment simultaneously have a significant effect on employee performance with the regression equation $Y=10.510+$ $0.452 X 1+0.302 X 2$ and the contribution of the influence is $55.7 \%$, hypothesis testing is obtained F count $>F$ table or $(42.054>2.740)$.

Keywords: Compensation, Work Environment, Employee Performance

\section{PENDAHULUAN}

Sumber daya manusia saat ini menjadi tantangan tersendiri bagi manajemen karena keberhasilan manajemen untuk menentukan perencanaan sumber daya manusia meliputi penyusunan anggaran sumber daya manusia dan penyusunan program tenaga kerja untuk mencapai tujuan organisasi (Mangkunegara, 2014:8).Walaupun di dukung oleh sarana dan prasarana serta sumber dana yang berlimpah dari perusahaan, tetapi tanpa dukungan sumber daya manusia yang handal dan baik program perusahaan tidak akan terselesaikan dengan baik. Hal ini menyatakan bahwa sumber daya manusia menunjukkan kunci pokok yang harus diperhatikan kebutuhannya.

Penilaian prestasi kerja merupakan proses melalui mana organisasiorganisasi mengevaluasi atau menilai prestasi kerja karyawan, kegiatan ini dapat memperbaiki keputusan-keputusan personalia dan memberikan umpan balik kepada para karyawan tentang pelaksanaan kerja mereka. Kinerja karyawan dapat di pengaruhi oleh beberapa faktor seperti faktor kemampuan dan faktor motivasi (Mangkunegara, 2014:67).

Mathis dan Jackson (2012:118) usaha 
yang harus di lakukan untuk meningkatkan kinerja karyawan adalah kompensasi, kompensasi merupakan faktor penting yang mempengaruhi bagaimana dan mengapa orang-orang bekerja pada suatu organisasi dan bukan pada perusahaan yang lainnya. Pengusaha harus cukup kompetitif dengan jenis kompensasi untuk mempekerjakan, mempertahankan, dan memberi imbalan terhadap kinerja setiap individu di dalam organisasi.
Dessler
(2014:46)
kompensasi

karyawan merujuk kepada semua bentuk bayaran atau hadiah bagi karyawan dan berasal dari pekerjaan mereka. Kompensasi karyawan memiliki dua komponen utama: pembayaran langsung dalam bentuk upah, gaji, insentif, komisi, dan bonus, dan pembayaran tidak langsung dalam bentuk tunjangan keuangan seperti asuransi dan liburan yang di bayar oleh perusahaan.

Hasibuan (2014:118) kompensasi adalah semua pendapatan yang berbentuk uang, barang langsung atau tidak langsung yang diterima karyawan sebagai imbalan jasa atas jasa yang diberikan kepada perusahaan. Kompensasi diharapkan mampu memotivasi karyawan agar dapat menyelesaikan pekerjaannya dengan baik, dengan adanya kompensasi yang memadai dan peningkatan motivasi yang dijalankan berhasil, maka seorang karyawan akan termotivasi dalam pelaksanaan pekerjaan yang dibebankan kepadanya dan berupaya mengatasi permasalahan yang terjadi serta meningkatkan kinerja karyawan (Mangkunegara, 2014:84).

$$
\text { Pimpinan perusahaan dalam }
$$
memberikan tugas dan tanggung jawab kepada karyawan hendaknya juga memperhatikan lingkungan kerja karyawan. Tata ruang di tempat kerja seperti mebel, pewarnaan, pencahayaan, pertukaraan udara, keamanan fisik, kualitas udara, informal dan daerah pertemuan formal, daerah tenang, privasi, penyimpanan pribadi, rungan kerja, dan sebagainya, berdampak terhadap kinerja karyawan, sehingga lingkungan kerja tidak hanya mempengaruhi semangat kerja dan gairah kerja tetapi dapat mempengaruhi kinerja karyawan (Nitisemito, 2012:183)

Leblebici (2012:2) beberapa faktorfaktor lingkungan kerja yang dapat mempengaruhi kinerja karyawan di antaranya minimnya keterlibatan pemimpin dalam pekerjaan, semangat kerja, dan kenyamanan dalam bekerja. Bekerja di lingkungan yang nyaman seperti teman kerja yang siap untuk membantu dan berinteraksi satu sama lain saat bekerja bahkan pimpinan perusahaan memperlakukan semua karyawan sama sehingga dapat menghasilkan peningkatan kinerja karyawan serta kinerja seluruh organisasi.

Blazovich (2013:165) menyimpulkan dari hasil penelitiannya bahwa kompensasi berpengaruh positif dan signifikan terhadap kinerja. Penelitian Blazovich (2013:165) di dukung oleh hasil penelitian Jamil dan Raja (2010:910) yang menyatakan kompensasi terbukti berpengaruh secara signifikan terhadap kinerja pegawai. Penelitian yang dilakukan oleh Shopiah (2013:87) Menyimpulkan bahwa kompensasi keuangan berpengaruh positif signifikan terhadap kinerja karyawan. Juniarti (2014:13) menyimpulkan hasil yang berbeda dari penelitian terdahulu bahwa kompensasi tidak berpengaruh signifikan terhadap kinerja karyawan perbankan. Maka variabel kompensasi tidak berpengaruh secara parsial terhadap kinerja karyawan Hasil Penelitian. Penelitian yang dilakukan Juniarti (2014:13) di dukung dengan hasil penelitian yang dilakukan oleh Rizal dkk. (2014:74) bahwa kompensasi tidak berpengaruh signifikan terhadap kinerja karyawan.

Menurut Sastrohadiwiryo (2013:181) "Kompensasi adalah imbalan atau jasa atau balas jasa yang diberikan oleh perusahaan kepada para tenaga kerja, karena tenaga kerja telah memberikan sumbangan tenaga dan pikiran demi kemajuan perusahaan guna mencapai tujuan yang telah di tetapkan".

PT. Indriya Lifeart Development adalah perusahaan yang bergerak di bidang tempat makan dan restoran yang diberi nama The Playground yang terletak di 
Plaza Indonesia ex, yang menawarkan menu dari berbagai benua. Pada tahun 2015 PT. Indriya Lifeart Development membuka sebuah usaha catering yang diberi nama Paton dan Preciosa. Untuk karyawan tetap dan kontrak di perusahaan ini diberikan

Tabel 1. Daftar Pemberian Kompensasi pada PT. Indriya Lifeart Development

\begin{tabular}{|c|c|c|c|c|c|}
\hline Tahun & Kinerja & Senioritas & Kebutuhan & $\begin{array}{c}\text { Keadilan dan } \\
\text { Kelayakan }\end{array}$ & $\begin{array}{c}\text { Evaluasi } \\
\text { jabatan }\end{array}$ \\
\hline 2018 & $2 \mathrm{x} / \mathrm{Th}^{*}$ & $\begin{array}{c}\text { Sangat } \\
\text { tejamin }\end{array}$ & Jenjang karir jelas & 2 xgaji pokok & $2 \times$ gaji pokok \\
\hline 2019 & $2 \mathrm{X} / \mathrm{Th}^{*}$ & Tidak ada & Tidak pasti & Proposional & Proposional \\
\hline 2020 & $1 \mathrm{x} / \mathrm{Th}$ & Jamsostek & $\begin{array}{c}\text { Tidak jelas bisa di } \\
\text { perpanjang bisa tidak }\end{array}$ & 1xgaji pokok & $1 \times$ gaji pokok \\
\hline
\end{tabular}

Sumber: PT. Indriya Lifeart Development (2020)

Adanya kesenjangan dalam pemberian kompensasi antara staf karyawan, pekerjan kontrak dan karyawan tetap.

Bercermin dari masalah tersebut, kompensasi menjadi faktor yang penting dalam upaya peningkatan kinerja karyawan, dengan kompensasi yang cukup dan dapat memenuhi kebutuhan karyawan, maka karyawan akan bekerja dengan baik. Menurut Handoko (2008:155) masalah kompensasi merupakan fungsi manajemenpersonalia yang paling sulit dan membingungkan. Tidak hanya karena pemberiankompensasi merupakan salah satu tugas yang paling kompleks, tetapi juga salah satu yang paling berarti bagi karyawan maupun organisasi. Apabila kompensasi yang diberikan perusahaan tidak tepat, perusahaan bisa kehilangan karyawan yang memiliki kinerja baik, dan perusahaan harus mengeluarkan biaya lagi untuk penarikan karyawan baru atau yang biasa kita sebut dengan istilah recruitment.

Selain masalah yang berhubungan dengan kompensasi, terdapat pula masalah lingkungan kerja yang ada di PT. Indriya Lifeart Development cabang Pondok Indah Mall. Lingkungan kerja menjadi komponen utama dimana pertama kali kontak dengan kompensasi berupa gaji, tunjangan, bonus kinerja setiap akhir tahunnya, dll, dan diberikan berdasarkan pada jabatan, pendidikan, masa kerja serta kemampuan masing-masing setiap pegawai.

dunia kerja dilakukan oleh seorang karyawan. Kenyamanan dalam bekerja seorang karyawan ditentukan oleh lingkungan kerja di sekitarnya. Semakin baik dan kondusif lingkungan kerja karyawan, kenyamanan kerja yang didapatkan pun akan semakin besar. Lingkungan kerja adalah sesuatu yang ada disekitar para pekerja dan yang mempengaruhi dirinya dalam menjalankan tugas-tugas yang dibebankan, hal ini berarti lingkungan kerja yang kondusif dan sesuai akan sangat berpengaruh terhadap kinerja karyawan. Baik buruknya kinerja pegawai dipengaruhi sedikit banyak oleh lingkungan kerja yang ada, semakin baik lingkungan yang ada semakin baik pula kinerja karyawan, begitu juga sebaliknya

Berdasarkan survei pendahuluan, peneliti menemukan adanya kekurang menaati tata tertib, Menurunnya kinerja karyawan PT. Indriya Lifeart Development terlihat dari turunnya pelayan karyawan terhadap konsumen. Kurang kondusifnya lingkungan kerja yang ada, terlihat dari hasil wawancara dengan karyawan PT. Indriya Lifeart Development. Berikut data absensia karyawan PT. Indriya Lifeart Development kurang mentaati peraturan data sebagai berikut:

Tabel 2. Rekapitulasi Penilaian Kinerja Karyawan PT. Indriya Lifeart Development Tahun 2018-2020

\begin{tabular}{|l|c|c|c|}
\hline \multicolumn{1}{|c|}{ Kriteria Penilaian } & $\mathbf{2 0 1 8}$ & $\mathbf{2 0 1 9}$ & $\mathbf{2 0 2 0}$ \\
\hline Kualitas hasil kerja & 72,5 & 66,5 & 62,1 \\
\hline Kuantitas hasil kerja & 75,9 & 67,5 & 62,1 \\
\hline Disiplin pegawai & 74,4 & 68,4 & 65,9 \\
\hline Tanggungjawab & 70,8 & 69,2 & 62,8 \\
\hline Kerjasama & 72,4 & 65,3 & 60,2 \\
\hline
\end{tabular}




\begin{tabular}{|l|c|c|c|}
\hline Kepemimpinan & 71,8 & 68,8 & 58,7 \\
\hline Prakarsa & 70,9 & 65,6 & 59,1 \\
\hline Keterampilan kerja & 72,5 & 62,5 & 60,1 \\
\hline Kejujuran & 69,4 & 64 & 59,2 \\
\hline Rata-rata & 71,6 & 691,8 & 66,2 \\
\hline
\end{tabular}

Sumber: Hasil pengolahan data dan penilaian kinerja

Keterangan: $\mathrm{SB}=80-100, \mathrm{~B}=60-79, \mathrm{CB}=40-59$

Berdasarkan tabel di atas, terlihat bahwa Penilaian Kinerja karyawan pada PT. Indriya Lifeart Development tahun 2015 sampai 2017 menurun hal ini disebabkan karena belum optimalnya pelaksanaan Penilaian Kinerja di PT. Indriya Lifeart Development sehingga mengakibatkan Penilaian Kinerja karyawan menjadi rendah. Hasil wawancara dengan kepala bagian sumber daya manusia PT. Indriya Lifeart Development menyatakan bahwa Penilaian Kinerja di PT. Indriya Lifeart Development secara rutin tiap tahun sekali

Kompensasi yang sesuai dan dapat memenuhi kebutuhan karyawan akan mendorong meningkatnya kinerja karyawan. Begitu juga dengan lingkungan kerja, dengan lingkungan kerja yang baik dan kondusif maka karyawan akan nyaman dalam bekerja, hal ini akan meningkatkan kinerja karyawan, karena karyawan dapat bekerja dengan baik. Sehingga karyawan yang mendapat kompensasi yang sesuai, serta ditunjang dengan lingkungan kerja yang kondusif akan dapat meningkatkan kinerja karyawan

Berdasarkan uraian di atas penulis tertarik untuk melakukan penelitian yang berjudul: "Pengaruh Kompensasi dan lingkungan kerja Terhadap Kinerja Karyawan pada PT. Indriya Lifeart Development".

\section{TINJAUAN PUSTAKA}

\section{Kompensasi}

Yang dimaksud kompensasi dalam penelitian ini adalah segala semua pemberian perusahaan kepada karyawan sebagai imbalan atau balas jasa atas jasa yang diberikan karyawan kepada perusahaan. Simamora (2014:445). Adapun indikator yang digunakan meliputi: 1) gaji dan upah, 2) intensif, 3) tunjangan, 4) fasilitas.

\section{Lingkungan kerja}

Yang dimaksud lingkungan kerja adalah keseluruhan alat perkakas dan bahan yang dihadapi, lingkungan sekitarnya dimana seseorang bekerja, metode kerjanya serta pengaturan kerjanya baik sebagai perseorangan maupun kelompok. Sedarmayanti (2015:21). Adapun indikator yang digunakan meliputi: 1) Penerangan, 2) Sirkulasi udara, 3) tata letak ruang, 4) privasi ruang kerja, 5) penggunaan warna, 6) peralatan kantor, 7) keamanan kerja, 8) musik tempat kerja.

\section{Kinerja Karyawan}

Yang dimaksud kinerja karyawan adalah hasil kerja secara kualitas dan kuantitas yang dicapai oleh seorang pegawai dalam melaksanakan tugasnya sesuai dengan tanggung jawab yang diberikan kepadanya. Mangkunegara (2016:75). Adapun indikator yang digunakan sebagai berikut: 1) Kualitas, 2) Kuntitas, 3) Pelaksanaan Tugas, 4) Tanggung Jawab

\section{METODE}

Populasi dalam penelitian ini berjumlah 70 responden PT. Indriya Lifeart Development di Jakarta. Sampel dalam penelitian ini berjumlah 70 responden. Jenis penelitian yang dipakai adalah kuantitatif, dimana tujuannya adalah untuk mengetahui pengaruh antara variabel bebas terhadap variabel terikat baik parsial maupun simultan. Dalam menganalisis data digunakan uji instrumen, uji asumsi klasik, regresi, koefisien korelasi, koefisien determinasi dan uji hipotesis. 
HASIL DAN PEMBAHASAN

\section{Analisis Deskriptif}

Pada pengujian ini digunakan untuk mengetahui skor minimum dan maksimum, mean score dan standar deviasi dari masing-masing variabel. Adapun hasilnya sebagai berikut:

Tabel 3. Hasil Analisis Descriptive Statistics

Descriptive Statistics

\begin{tabular}{lr|r|r|r|r} 
& N & Minimum & Maximum & Mean & Std. Deviation \\
\hline Kompensasi (X1) & 70 & 31 & 48 & 38.04 & 4.265 \\
\hline Lingkungan Kerja (X2) & 70 & 30 & 48 & 38.24 & 3.801 \\
\hline Kinerja Karyawan (Y) & 70 & 33 & 46 & 39.24 & 3.617 \\
\hline Valid N (listwise) & 70 & & & & \\
\hline
\end{tabular}

Kompensasi diperoleh varians minimum sebesar 31 dan varians maximum 48 dengan mean score sebesar 38,04 dengan standar deviasi 4,265.

Lingkungan kerja diperoleh varians minimum sebesar 30 dan varians maximum 48 dengan mean score sebesar 38,24 dengan standar deviasi 3,801.

Kinerja karyawan diperoleh varians minimum sebesar 33 dan varians maximum 46 dengan mean score sebesar 39,24 dengan standar deviasi 3,617.

\section{Analisis Kuantitatif.}

Pada analisis ini dimaksudkan untuk mengetahui pengaruh variabel independen terhadap variabel dependen. Adapun hasil pengujian sebagai berikut:

\section{a. Analisis Regresi Linier Berganda}

Uji regresi ini dimaksudkan untuk mengetahui perubahan variabel dependen jika variabel independen mengalami perubahan. Adapun hasil pengujiannya sebagai berikut:

Tabel 4. Hasil Pengujian Regresi Linier Berganda

Coefficients $^{a}$

Unstandardized Standardized Coefficients Coefficients

\begin{tabular}{|c|c|c|c|c|c|c|}
\hline \multirow{2}{*}{\multicolumn{2}{|c|}{ Model }} & \multicolumn{2}{|c|}{ Coefficients } & \multirow{2}{*}{$\begin{array}{c}\text { Coefficients } \\
\text { Beta }\end{array}$} & \multirow[b]{2}{*}{$\mathrm{t}$} & \multirow[b]{2}{*}{ Sig. } \\
\hline & & B & $\begin{array}{l}\text { Std. } \\
\text { Error }\end{array}$ & & & \\
\hline 1 & (Constant) & 10.510 & 3.246 & & 3.237 & .002 \\
\hline & Kompensasi (X1) & .452 & .080 & .533 & 5.644 & .000 \\
\hline & $\begin{array}{l}\text { Lingkungan Kerja } \\
\text { (X2) }\end{array}$ & 301 & .090 & .317 & 3.349 & .001 \\
\hline
\end{tabular}

a. Dependent Variable: Kinerja Karyawan $(\mathrm{Y})$

Berdasarkan hasil pengujian pada tabel di atas, diperoleh persamaan regresi $\mathrm{Y}=10,510+$ 0,452X1 + 0,302X2. Dari persamaan tersebut dijelaskan sebagai berikut:

1) Konstanta sebesar 10,510 diartikan jika kompensasi dan lingkungan kerja tidak ada, maka telah terdapat nilai kinerja karyawan sebesar 10,510 point.

2) Koefisien regresi kompensasi sebesar 0,452, angka ini positif artinya setiap ada peningkatan kompensasi sebesar 0,452 maka kinerja karyawan juga akan mengalami peningkatan sebesar 0,452 point.

3) Koefisien regresi lingkungan kerja sebesar 0,302, angka ini positif artinya setiap ada peningkatan lingkungan kerja sebesar 0,302 maka kinerja karyawan juga akan mengalami peningkatan sebesar 0,302 point.

\section{b. Analisis Koefisien Korelasi}

Analisis koefisien korelasi dimaksudkan untuk mengetahui tingkt kekuatan hubungan dari variabel independen terhadap 
variabel dependen baik secara parsial pengujian sebagai berikut: maupun simultan. Adapun hasil

Tabel 5. Hasil Pengujian Koefisien Korelasi Kompensasi Terhadap Kinerja Karyawan.

Correlations $^{\mathrm{b}}$

\begin{tabular}{llr|r} 
& & $\begin{array}{c}\text { Kompensasi } \\
(\mathrm{X} 1)\end{array}$ & \multicolumn{1}{c}{$\begin{array}{c}\text { Kinerja } \\
\text { Karyawan (Y) }\end{array}$} \\
\hline Kompensasi (X1) & Pearson Correlation & 1 & $.695^{* *}$ \\
\cline { 2 - 4 } & Sig. (2-tailed) & & .000 \\
\hline Kinerja Karyawan (Y) & Pearson Correlation & $.695^{* *}$ & 1 \\
\cline { 2 - 4 } & Sig. (2-tailed) & .000 & \\
\hline \multirow{2}{*}{ **. Correlation is significant at the 0.01 level (2-tailed). } & & \\
b. Listwise N=70 &
\end{tabular}

Berdasarkan hasil pengujian hubungan yang kuat terhadap kinerja diperoleh nilai korelasi sebesar 0,695 artinya kompensasi memiliki karyawan.

Tabel 6. Hasil Pengujian Koefisien Korelasi Lingkungan kerja Terhadap Kinerja Karyawan.

Correlations $^{\mathrm{b}}$

\begin{tabular}{|c|c|c|c|}
\hline & & $\begin{array}{l}\text { Lingkungan } \\
\text { Kerja }(\mathrm{X} 2)\end{array}$ & $\begin{array}{c}\text { Kinerja Karyawan } \\
(Y)\end{array}$ \\
\hline \multirow{2}{*}{$\begin{array}{l}\text { Lingkungan Kerja } \\
(\mathrm{X} 2)\end{array}$} & Pearson Correlation & 1 & $.588^{* *}$ \\
\hline & Sig. (2-tailed) & & .000 \\
\hline \multirow[t]{2}{*}{ Kinerja Karyawan $(\mathrm{Y})$} & Pearson Correlation & $.588^{* *}$ & 1 \\
\hline & Sig. (2-tailed) & .000 & \\
\hline
\end{tabular}

**. Correlation is significant at the 0.01 level (2-tailed).

b. Listwise $\mathrm{N}=70$

Berdasarkan hasil pengujian diperoleh nilai korelasi sebesar 0,588 artinya lingkungan kerja memiliki

Tabel 7. Hasil Pengujian Koefisien Korelasi Kompensasi dan Lingkungan kerja secara simultan Terhadap Kinerja Karyawan.

Model Summary

\begin{tabular}{lr|r|rr|r} 
Model & $\mathrm{R}$ & R Square & $\begin{array}{c}\text { Adjusted R } \\
\text { Square }\end{array}$ & \multicolumn{2}{|c}{$\begin{array}{c}\text { Std. Error of the } \\
\text { Estimate }\end{array}$} \\
\hline 1 & $.746^{\mathrm{a}}$ & .557 & .543 & 2.444 \\
\hline
\end{tabular}

a. Predictors: (Constant), Lingkungan Kerja (X2), Kompensasi (X1)

Berdasarkan hasil pengujian diperoleh nilai korelasi sebesar 0,746 artinya kompensasi dan lingkungan kerja secara simultan memiliki hubungan yang kuat terhadap kinerja karyawan. hubungan yang sedang terhadap kinerja karyawan. 
Berdasarkan hasil pengujian diperoleh nilai determinasi sebesar 0,482 artinya kompensasi memiliki

Tabel 9. Hasil Pengujian Koefisien Determinasi Lingkungan kerja Terhadap Kinerja Karyawan.

Model Summary

\begin{tabular}{l|r|r|r|r} 
Model & R & R Square & $\begin{array}{c}\text { Adjusted R } \\
\text { Square }\end{array}$ & \multicolumn{2}{c}{$\begin{array}{c}\text { Std. Error of the } \\
\text { Estimate }\end{array}$} \\
\hline 1 & $.588^{\mathrm{a}}$ & .346 & .336 & 2.947 \\
\hline
\end{tabular}

a. Predictors: (Constant), Lingkungan Kerja (X2)

Berdasarkan hasil pengujian diperoleh nilai determinasi sebesar 0,346 artinya lingkungan kerja

Tabel 10. Hasil Pengujian Koefisien Determinasi Kompensasi dan Lingkungan kerja Terhadap Kinerja Karyawan.

Model Summary

\begin{tabular}{l|c|cc|c} 
Model & $\mathrm{R}$ & R Square & $\begin{array}{c}\text { Adjusted R } \\
\text { Square }\end{array}$ & \multicolumn{2}{c}{$\begin{array}{c}\text { Std. Error of the } \\
\text { Estimate }\end{array}$} \\
\hline 1 & $.746^{\mathrm{a}}$ & .557 & .543 & 2.444 \\
\hline a. Predictors: (Constant), Lingkungan Kerja (X2), Kompensasi (X1)
\end{tabular}

Berdasarkan hasil pengujian diperoleh nilai determinasi sebesar 0,557 artinya kompensasi dan lingkungan kerja secara simultan memiliki kontribusi pengaruh sebesar $55,7 \%$ terhadap kinerja karyawan, sedangkan sisanya sebesar 44,3\% dipengaruhi faktor lain. memiliki kontribusi pengaruh sebesar $34,6 \%$ terhadap kinerja karyawan. kontribusi pengaruh sebesar 48,2\% terhadap kinerja karyawan. 
Berdasarkan hasil pengujian pada tabel di atas, diperoleh nilai $\mathrm{t}$ hitung > t tabel atau (5,995 > 1,995), dengan demikian hipotesis kedua yang diajukan bahwa terdapat pengaruh yang signifikan atara lingkungan kerja terhadap kinerja karyawan diterima.
Uji Hipotesis Simultan (Uji F)

Pengujian hipotesis dengan uji $\mathrm{F}$ digunakan untuk mengetahui hipotesis simultan yang mana yang diterima.

Hipotesis ketiga Terdapat pengaruh yang signifikan antara kompensasi dan lingkungan kerja terhadap kinerja karyawan.

Tabel 13. Hasil Uji Hipotesis Kompensasi dan Lingkungan kerja Terhadap Kinerja Karyawan.

\begin{tabular}{|c|c|c|c|c|c|c|}
\hline \multirow[b]{2}{*}{ Model } & & \multicolumn{2}{|c|}{ ANOVA $^{a}$} & & \multirow[b]{2}{*}{$\mathrm{F}$} & \multirow[b]{2}{*}{ Sig. } \\
\hline & & Sum of Squares & $\mathrm{df}$ & $\begin{array}{l}\text { Mean } \\
\text { Square }\end{array}$ & & \\
\hline 1 & Regression & 502.547 & 2 & 251.273 & 42.054 & $.000^{\mathrm{b}}$ \\
\hline & Residual & 400.325 & 67 & 5.975 & & \\
\hline & Total & 902.871 & 69 & & & \\
\hline
\end{tabular}

a. Dependent Variable: Kinerja Karyawan $(\mathrm{Y})$

b. Predictors: (Constant), Lingkungan Kerja (X2), Kompensasi (X1)

Berdasarkan hasil pengujian pada tabel di atas, diperoleh nilai $\mathrm{F}$ hitung > F tabel atau $(42,054>2,740)$, dengan demikian hipotesis ketiga yang diajukan bahwa terdapat pengaruh yang signifikan atara kompensasi dan lingkungan kerja terhadap kinerja karyawan diterima.

\section{PEMBAHASAN HASIL PENELITIAN}

\section{Pengaruh Kompensasi Terhadap} Kinerja Karyawan

Kompensasi berpengaruh signifikan terhadap kinerja karyawan dengan korelasi sebesar 0,695 atau memiliki hubungan yang kuat dengan kontribusi pengaruh sebesar 48,2\%. Pengujian hipotesis diperoleh nilai $t$ hitung $>\mathrm{t}$ tabel atau $(7,960>1,995)$. Dengan demikian hipotesis pertama yang diajukan bahwa terdapat berpengaruh signifikan antara kompensasi terhadap kinerja karyawan diterima.

\section{Pengaruh Lingkungan kerja Terhadap} Kinerja Karyawan

Lingkungan kerja berpengaruh signifikan terhadap kinerja karyawan dengan korelasi sebesar 0,588 atau memiliki hubungan yang sedang dengan kontribusi pengaruh sebesar $34,6 \%$.
Pengujian hipotesis diperoleh nilai $t$ hitung $>\mathrm{t}$ tabel atau $(5,995>1,995)$. Dengan demikian hipotesis kedua yang diajukan bahwa terdapat berpengaruh signifikan antara lingkungan kerja terhadap kinerja karyawan diterima.

\section{Pengaruh Kompensasi dan Lingkungan kerja Terhadap Kinerja Karyawan}

Kompensasi dan lingkungan kerja berpengaruh signifikan terhadap kinerja karyawan dengan diperoleh persamaan regresi $Y=10,510+0,452 X 1+0,302 X 2$, nilai korelasi sebesar 0,746 atau memiliki hubungan yang kuat dengan kontribusi pengaruh sebesar $55,7 \%$ sedangkan sisanya sebesar $44,3 \%$ dipengaruhi faktor lain. Pengujian hipotesis diperoleh nilai $\mathrm{F}$ hitung > F tabel atau $(42,054>2,740)$. Dengan demikian hipotesis ketiga yang diajukan bahwa terdapat berpengaruh signifikan antara kompensasi dan lingkungan kerja terhadap kinerja karyawan diterima.

\section{PENUTUP}

\section{Kesimpulan}

1. Kompensasi berpengaruh signifikan terhadap kinerja karyawan dengan kontribusi pengaruh sebesar $48,2 \%$. Uji hipotesis diperoleh nilai thitung $>\mathrm{t}$ tabel 
atau $(7,960>1,995)$.

2. Lingkungan kerja berpengaruh signifikan terhadap kinerja karyawan dengan kontribusi pengaruh sebesar $34,6 \%$. Uji hipotesis diperoleh nilai $t$ hitung $>\mathrm{t}$ tabel atau $(5,995>1,995)$.

3. Kompensasi dan lingkungan kerja berpengaruh signifikan terhadap kinerja karyawan dengan kontribusi pengaruh sebesar $55,7 \%$ sedangkan sisanya sebesar $44,3 \%$ dipengaruhi faktor lain. Uji hipotesis diperoleh nilai $\mathrm{F}$ hitung $>\mathrm{F}$ tabel atau $(42,054>2,740)$.

\section{Saran}

1. Variabel kompensasi pernyataan yang paling lemah adalah terkait dengan fasilitas terutama pada pernyataan perusahaan menyediakan sarana prasarana kerja yang mendukung pekerjaan dimana hanya mencapai score sebesar 3,56. Untuk lebih baik lagi perusahaan harus melengkapi sarana prasarana yang diperlukan karyawan dalam menunjang pekerjaannya

2. Variabel lingkungan kerja pernyataan yang paling lemah adalah terkait dengan perlatan kantor terutama pernyataan penataan ruang sudah di desaign dengan nyaman dimana hanya mencapai score sebesar 3,63. Untuk lebih baik lagi perusahaan harus menata ruang kantor maupun restoran agar lebih nyaman.

3. Variabel kinerja karyawan pernyataan yang paling lemah adalah terkait dengan kuantitas pekerjaan terutama pernyataan perusahaan mengapresiasi pekerja yang mencapai kuantitas kerja tertentu, dimana hanya mencapai score sebesar 3,73 . Untuk lebih baik lagi perusahaan harus secara berkala memberikan apresiasi baik penghargaan berupa materi berupa uang maupun penghargaan non materi seperti pemberian piagam penghargaan, ucapan terma kasih secara resmi atau formal dari perusahaan kepada karyawan yang memiliki kinerja yang terbaik
DAFTAR PUSTAKA

Affandi, A., Sarwani, A. S., Erlangga, H., Siagian, A. O., Purwanto, A., Effendy, A. A., ... \& Wahyitno, C. D. M. (2020). Optimization of MSMEs Empowerment in Facing Competition in the Global Market during the COVID-19 Pandemic Time. Systematic Reviews in Pharmacy, 11(11), 1506-1515. Ahmad, Komarudin. (1996). Dasar-dasar Manajemen Investasi. Jakarta: Rineka. Cipta.

Alma, B (2011). “Manajemen Pemasaran dan Pemasaran Jasa". Cetakan kelima. Edisi Revisi. Bandung: Alfabeta.

Arikunto, Suharsimi, (2015). Prosedur Penelitian Suatu Pendekatan Praktek, PT. Rineka Cipta, Jakarta.

Dessler, Gerry, (2014) Human Resources Management. Prenticehall, International Inc, London.

Edi Sutrisno. (2012). Sumber Daya Manusia, PT. Gramedia, Surabaya,

Edwin B Flippo, (2014). Prinsip-Prinsip Sumber Daya Manusia. Edisi ke Duabelas, Erlangga, Jakarta.

Ghozali (2017). Aplikasi Analisis Multivariate dengan Program SPSS", Edisi Kelima, Badan Penerbit Undip, Semarang.

Handoko. (2012). Manajemen Personalia dan Sumberdaya Manusia, Edisi Kelima, BPFE UGM, Yogyakarta.

Hermawati, R., \& Mariza, M. (2019). Pengaruh Keselamatan Kerja Dan Pelatihan Terhadap Kinerja Karyawan Pada PT. Aerofood Catering Service Divisi Laundry Tangerang. Jurnal Semarak, 2(3).

Husain, B. A. (2020). Pengaruh Kompensasi Terhadap Disiplin Kerja Karyawan Pada PT. Strategic Pestcontrol Tebet Jakarta Selatan. JENIUS (Jurnal Ilmiah Manajemen Sumber Daya Manusia), 3(3), 277-285.

Husein Umar, (1998), Metode Penelitian, Jakarta, Raja Grafindo Persada.

Kaso, N., Nurjihad, A., Ilham, D., \& Aswar, N. (2021). Facebook and its Impact on Students' Learning Achievement at State Islamic High School of Palopo. 
Jurnal Studi Guru dan Pembelajaran, 4(1), 1-15.

Mathis, Robert. L \& Jackson John.H, (2014) Manajemen Sumber Daya Manusia. Jilid 1, Salemba Empat, Jakarta.

Michael R Carrell, (2015). Human Resourcee Managemen Global for managing Diverse Wokplace, Edition, Prenice Hall Inc. Nre Jersey.

Miftah Thoha. (2012). Kepemimpinan Dalam Manajemen, Edisi Pertama, PT. Raja Grafindo, Jakarta

Muskamal. (2010). Analisis Beban Kerja Organisasi Pemerintah Daerah. PKP2A II. LAN Makassar.

Nilasari, Irma dan Sri Wiludjeng, (2006), Pengantar Bisnis, Graha. Yogyakarta Ilmu

NoerAlie Ramdani Suryana, Jurnal Ilmiah Widya Ekonomika (2018), ISSN: 23387807, Vol.2 No.1, Pengaruh Gaya Kepemimpinan dan Kompensasi Terhadap Kinerja Karyawan PT. A.W Fabercastell

Noor Arifin (2012), Analisis Kualitas Kehidupan Kerja, Kinerja dan Kepuasan Kerja pada CV Duta Senenan Jepara, Jurnal Economia, Volume 8, Nomor 1. Perawat di Tiap Ruang Rawat Inap RSUD Sidikalang. Tesis (Tidak Dipubikasi).

Nurjaya, N., Sunarsi, D., Effendy, A. A., Teriyan, A., \& Gunartin, G. (2021). Pengaruh Etos Kerja Dan Disiplin Kerja Terhadap Kinerja Pegawai Pada Dinas Kehutanan Dan Perkebunan Kota Bogor. JENIUS (Jurnal Ilmiah Manajemen Sumber Daya Manusia), $4(2), 172-184$.

Robbins, Stephen dan Mary Coulter, (2012). Manajemen, PT. Indeks Kelompok Gramedia, Jakarta,.

Samsudin, Sadili, (2015). Sumber Daya Manusia, Cetakan Kesatu, PT. Pustaka Setia, Jakarta

Sarwoto, (2011). Dasar-Dasar Manajemen Sumber Daya Manusia, Cetakan Keenambelas, Ghalia Indonesia, Jakarta.

Sedarmayanti. (2014). Manajemen Sumber Daya Manusia, Reformasi Birokrasi dan Manajemen Pegawai Negeri Sipil", Cetakan Kelima, PT Refika Aditama, Bandung.

Siagian (2012). Kiat Meningkatkan Produktivitas Kerja, PT. Rineka Cipta, Jakarta.

Siswanto dan Agus, (2013). Manajemen Sumber Daya Manusia. PT. Gramedia Pustaka, Jakarta.

Sugiyono, (2017). Metode Penelitian Kuantitatif Kualitatif dan R \& D", Penerbit CV. Alfabeta, Bandung.

Suharsimi Arikunto (2015). Prosedur Penelitian Suatu Pendekatan Praktek, PT. Rineka Cipta, Jakarta.

Sunarsi, D. (2017). Pengaruh Disiplin, Motivasi, Dan Kompetensi Terhadap Prestasi Belajar (Studi Kasus Pada Mahasiswa Universitas Pamulang, Tangerang Selatan Tahun Akademik 2016-2017). Jurnal Mandiri: Ilmu Pengetahuan, Seni, Dan Teknologi, 1(2), 207-226.

Suryani, N. L., \& Kristianti, L. S. (2020). Pengaruh Insentif Terhadap Kinerja Karyawan Pada PT. Trimegah Perkasa Di Jakarta. JENIUS (Jurnal Ilmiah Manajemen Sumber Daya Manusia), 4(1), 96-104.

Sutrisno, Edi., (2014). Pengaruh Disiplin kerja dan Budaya Organisasi Terhadap Kinerja Karyawan Devisi Radiologi RSUD Karidi Semarang. Vol. 12 No.2.

Terry, George R \& Rue, Leslie W. Rue, (2010) Dasar-Dasar Manajemen. Jakarta Bumi Aksara, Jakarta.

Thomas S. dan Snell, Scott A, (2013). "Management The New Competitive", Landscape. Sixth Edition. McGraw Hill. New York.

Veithzal Rivai dan Dedy Mulyadi, (2011). Kepemimpinan dan Perilaku Organisasi, Jakarta: PT. Raja Grafindo Persada.

W.F. Cascio dalam Robbins, (2012). Managing Human resources productivity of Work", Edisi ketujuh, terjemahan, Jakarta.

Wibowo, (2014) Manajemen Kinerja. PT. Raja Grafindo Persada, Jakarta. 